Progress in Commutative Algebra 1 



\title{
Progress in \\ Commutative Algebra 1
}

Combinatorics and Homology

\author{
edited by \\ Christopher Francisco \\ Lee Klingler \\ Sean Sather-Wagstaff \\ Janet C. Vassilev
}

De Gruyter 

ries working with Knowledge Unlatched. KU is a collaborative initiative designed to make high quality books Open Access. More information about the initiative can be found at www.knowledgeunlatched.org

\section{(cc) BY-NC-ND}

This work is licensed under the Creative Commons Attribution-NonCommercial-NoDerivs 4.0 License. For details go to http://creativecommons.org/licenses/by-nc-nd/4.0/.

ISBN 978-3-11-025034-3

e-ISBN 978-3-11-025040-4

\section{Library of Congress Cataloging-in-Publication Data}

A CIP catalog record for this book has been applied for at the Library of Congress.

\section{Bibliographic information published by the Deutsche Nationalbibliothek}

The Deutsche Nationalbibliothek lists this publication in the Deutsche Nationalbibliografie; detailed bibliographic data are available in the Internet at http://dnb.dnb.de.

(C) 2012 Walter de Gruyter GmbH \& Co. KG, Berlin/Boston

Typesetting: Da-TeX Gerd Blumenstein, Leipzig, www.da-tex.de

Printing: Hubert \& Co. GmbH \& Co. KG, Göttingen

$\infty$ Printed on acid-free paper

Printed in Germany

www.degruyter.com 